\title{
Gold, platinum and palladium enrichments in arcs: role of mantle wedge, arc crust and halogen-rich slab fluids
}

\author{
Pavel Kepezhinskas, ${ }^{1, *}$, Nikita Kepezhinskas $^{2}$, and Nikolai Berdnikov ${ }^{3}$ \\ ${ }^{1}$ PNK GeoScience, Tampa, Florida, USA \\ ${ }^{2}$ Department of Geological Sciences, University of Florida, Gainesville, Florida, USA \\ ${ }^{3}$ Institute of Tectonics and Geophysics, Khabarovsk, Russian Federation
}

\begin{abstract}
Arc-related magmas are frequently enriched in $\mathrm{Au}, \mathrm{Pt}$ and $\mathrm{Pd}$ in respect to MORB and OIB igneous suites. Magmatic arcs commonly host large-scale hydrothermal $\mathrm{Au}$ and $\mathrm{Au}-\mathrm{Cu}$ and PGE mineralization related to young volcanic systems and zoned ultramafic complexes respectively. Island-arc mantle xenoliths show $\mathrm{Au}, \mathrm{Pt}, \mathrm{Pd}$ enrichments related to mantle wedge metasomatism by slab-derived fluids. Long-lived plumbing systems in arc crust (arc magma chambers) show further enhancement of $\mathrm{Au}, \mathrm{Pt}$ and Pd enrichments through subduction-related metamorphic and metasomatic processes in the presence of halogen-rich, aqueous fluids. We propose that Au-Pt-Pd enrichments in arcs are caused by mantle wedgeslab interactions followed by differentiation and metamorphism of magmatic conduits in arc crust.
\end{abstract}

Gold, platinum and palladium enrichments are common in igneous rocks and magmatic/hydrothermal mineralization in subduction zones. Volcanic arcs host giant epithermal gold and copper porphyry systems [1-3], while subduction-related ultramafic rocks carry substantial PGE and $\mathrm{Cu}-\mathrm{Au}$ mineralization [4]. These geochemical signatures are commonly explained by crustal differentiation of arc-related mafic to felsic magmas coupled with magmatic column-supported development of deep hydrothermal systems $[5,6]$. We examine in this paper potential inputs of various mantle and crustal sources into precious metal enrichments at modern and fossil active continental margins.

\section{Role of sub-arc mantle wedge}

Mantle-wedge xenoliths (peridotites and pyroxenites) in Kamchatka display evidence for multi-stage metasomatism by slab-derived melts and fluids reflected in their modal mineralogy, trace elements and isotope characteristics [4,7,8]. Kamchatka ultramafic nodules show enrichment in $\mathrm{Pt}, \mathrm{Pd}$ and $\mathrm{Au}[4,8]$, as well as clear fractionations between the Ir- (Ir, Ru, Os) and the Pd- (Rh, Pd, Pt)-group PGEs (Table 1) suggesting that island-arc

*Corresponding author: pavel_k7@yahoo.com 
mantle (IAM) is enriched in $\mathrm{Pt}$ and $\mathrm{Au}$, and to a lesser extent, $\mathrm{Pd}$ in comparison to the primitive and continental lithospheric mantle sources (Table 1).

Table 1. PGE and Au ratios in various mantle sources and arc-related ultramafic-mafic complexes.

\begin{tabular}{|c|c|c|c|c|c|}
\hline & PM & CLM & IAM & UAC & ILC \\
\hline $\mathrm{Pt} / \mathrm{Pd}$ & 1.75 & 1.80 & 4.17 & 3.89 & 1.00 \\
\hline $\mathrm{Pt} / \mathrm{Os}$ & 1.98 & 1.75 & 5.44 & 42.6 & - \\
\hline $\mathrm{Pt} / \mathrm{Ir}$ & 1.87 & 1.89 & 4.41 & 17.7 & 5.71 \\
\hline $\mathrm{Au} / \mathrm{Os}$ & 0.29 & 0.16 & 1.39 & 2.58 & - \\
\hline $\mathrm{Au} / \mathrm{Ir}$ & 0.57 & 0.18 & 1.32 & 1.70 & 632.4 \\
\hline $\mathrm{Pd} / \mathrm{Os}$ & 1.05 & 0.98 & 1.74 & 10.4 & - \\
\hline $\mathrm{Pd} / \mathrm{Ir}$ & 1.00 & 1.05 & 1.65 & 6.88 & 5.74 \\
\hline
\end{tabular}

Note. PM- primitive mantle, CLM- continental lithospheric mantle, IAM- island-arc mantle, UACUral-Alaskan complexes, ILC- Ildeus-Lucha complex (Mesozoic Stanovoy arc, SE Siberia). Data sources and compilation of PGE+Au values for PM, CLM, IAM and UAC are presented in [4]. PGE and Au data for the ILC are from this study.

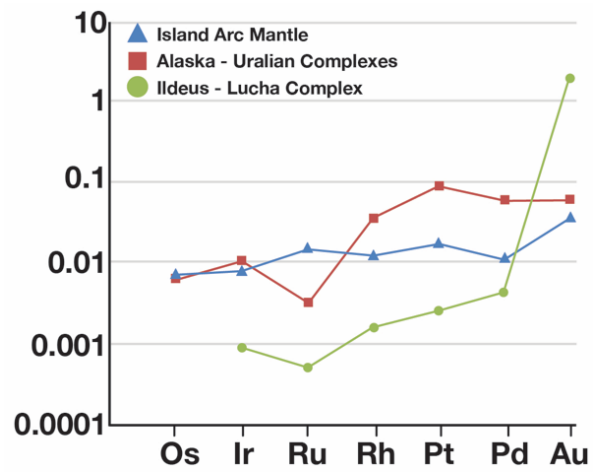

Fig. 1. Chondrite-normalized distributions of platinum-group elements and gold in average IslandArc Mantle [4], Alaskan-Uralian Complexes [4] and Ildeus-Lucha ultramafic complex, Stanovoy super-terrane (analyses by ICP-MS at the Khabarovsk Analytical Innovation Center,,Russia).

PGE and Au distribution in the Ural-Alaska type ultramafic complexes is similar to the average IAM (Figure 1). Ural-Alaska intrusions are believed to form via crystal fractionation of primitive melts (picrites or arc ankaramites) derived from sub-arc mantle wedge sources $[4,9,10]$. Their Pt signatures (and associated PGE mineralization) can be thus reflecting Pt-enrichments in the mantle wedge due to sub-arc metasomatism $[4,7,8]$ and/or to the fractionation of Pt-alloys during crustal differentiation of arc-related primary magmas $[9,10]$. High gold contents in some arc-related ultramafics such as the IldeusLucha complex (ILC; Table 1) in the Mesozoic Stanovoy arc can be linked to metasomatic enrichment of sub-arc mantle sources by auriferous slab-derived $\left(\mathrm{H}_{2} \mathrm{O}+\mathrm{Cl}\right)$ fluids.

\section{Magmatic and metamorphic processes in arc crust}

The Ildeus-Lucha ultramafic-mafic complex (ILC) represents a long-lived magmatic plumbing system emplaced at $233 \mathrm{Ma}(\mathrm{U}-\mathrm{Pb}$ zircon) in the crust of the Stanovoy arc and subjected to intense hydrothermal alteration followed by subduction-related amphibolite metamorphism at $\sim 140 \mathrm{Ma}$ [11]. ILC was later intruded by post-collision adakites and shoshonitic lamprophyres around 117-115 Ma [11]. Pronounced enrichment in large-ion lithophile ( $\mathrm{Cs}, \mathrm{Rb}, \mathrm{Ba}, \mathrm{Sr}, \mathrm{U})$ and depletion in high-field strength $(\mathrm{Nb}, \mathrm{Ta}, \mathrm{Zr}$ ) elements in ILC rocks suggest derivation from a subduction-related source. Main rock types are plagioclase- and amphibole-bearing dunite, wehrlite, pyroxenite and gabbro composed of 
Mg-rich olivine with extremely low $\mathrm{Al}, \mathrm{Ca}$ and high $\mathrm{Mn}$ contents and $\mathrm{Cr}$-magnetite, pargasitic amphibole along with serpentine, tremolite and chlorite and relics of magmatic clino- and orthopyroxenes [11]. This complex mineralogy reflects chemical changes during transition from subduction-related greenschist to collision-related amphibolite metamorphism in the arc-related crustal magma chamber (Figure 2). ILC rocks contain abundant sulfide mineralization, which includes pentlandite, Co-pentlandite (7-16 wt.\% $\mathrm{CoO}$ ), chalcopyrite, bornite, hazelwoodite, digenite, Ni-pyrite, Ni-sphalerite and a $\mathrm{Co}-\mathrm{Cu}$ sulfide phase. Native gold, $\mathrm{Au}-\mathrm{Ag}, \mathrm{Ni}-\mathrm{Ag}-\mathrm{Au}-\mathrm{Cu}, \mathrm{Ag}-\mathrm{Ni}-\mathrm{Pb}-\mathrm{Te}, \mathrm{Pb}-\mathrm{Sb}$ alloys along with $\mathrm{Au}$-rich chalcopyrite and $\mathrm{Cu}-\mathrm{Zn}$-bearing, Ag-rich barite are observed in some wehrlite and pyroxenite samples [11]. Cr-magnetite and sulfides in ILC pyroxenites frequently contain sobolevskite (PdBi) (Figure 3).

\section{Slab-derived geochemical signature: halogen-rich aqueous fluids}

Although traditional view associates trace element and metal mobility in subduction zones with water-silicate fluids [12], recent experimental data [13] and direct measurements of chlorine in basaltic glasses from Lau [14] and Manus [15] back-arc basins suggest that halogens play an important role in mantle wedge metasomatism and formation of island-arc magmas and associated ore deposits. Inclusions of potassic chloride in metamorphic olivine and pargasite in association with sulfides in the ILC rocks suggest involvement of saline metasomatic fluids derived from a downgoing slab during subduction-related amphibolite metamorphism ( $\sim 140 \mathrm{Ma})$. The ILC rocks were intruded by gold-bearing, post-collisional

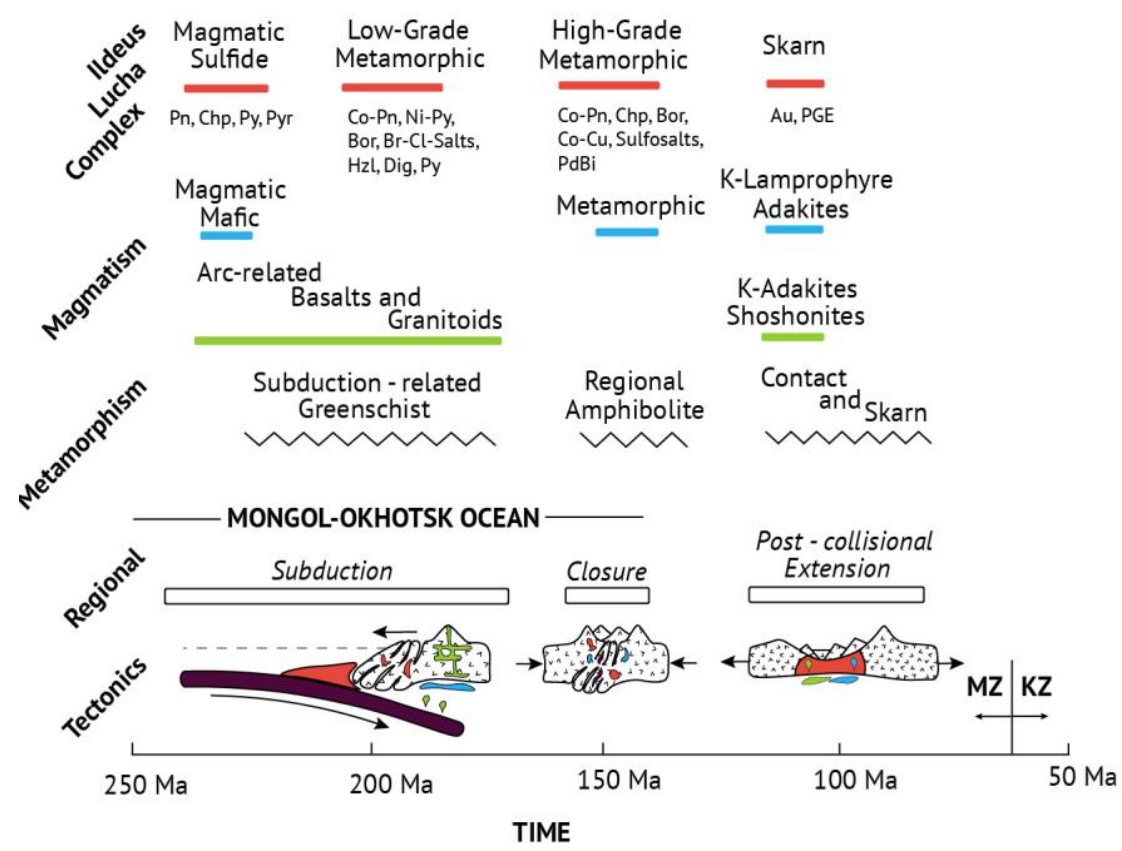

Fig. 2. Tectonic, magmatic and metamorphic events, which led to the formation of Ni-Co-Cu-PGEAu mineralization at the Ildeus-Lucha complex. Mineral abbreviations: Pn- pentlandite, Chpchalcopyrite, Py- pyrite, Pyr- pyrrhotite, Co-Pn- cobalt-rich (10-17\% Co) pentlandite, Ni-Pynickeliferous (1-8\% Ni) pyrite, Bor- bornite, Hzl- hazelwoodite $\left(\mathrm{Ni}_{3} \mathrm{~S}_{2}\right)$, Dig- digenite $\left(\mathrm{Cu}_{9} \mathrm{~S}_{5}\right), \mathrm{Co}-\mathrm{Cu}$ - Co-Cu sulfide. 

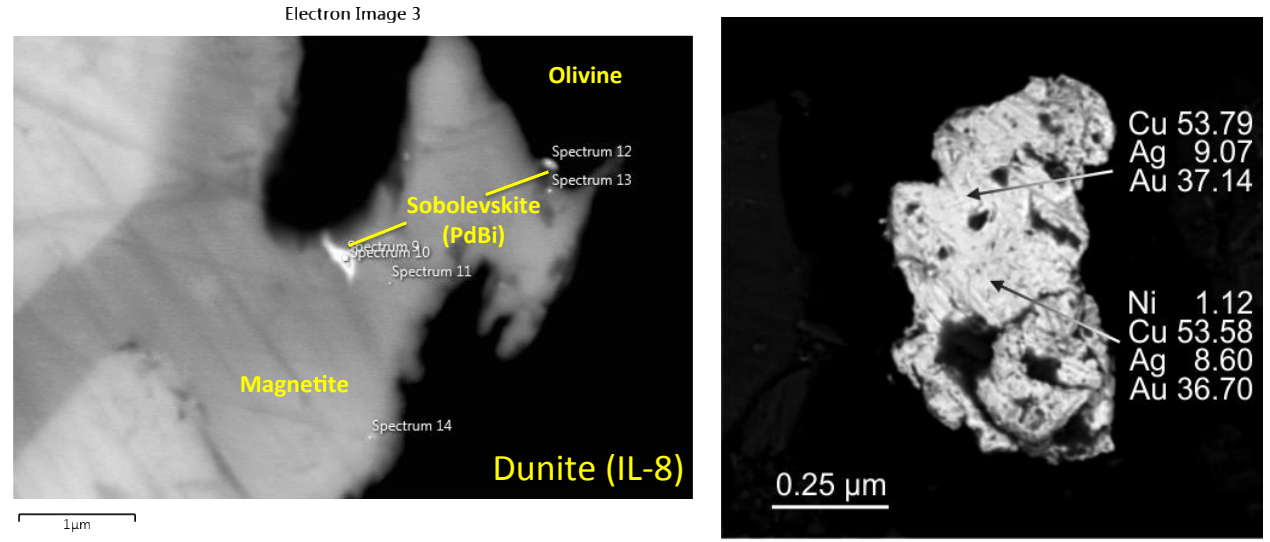

Fig. 3. Occurrence of sobolevskite (PdBi; left image) and $\mathrm{Ni}-\mathrm{Ag}-\mathrm{Au}-\mathrm{Cu}$ alloys (right image) in ILC ultramafic rocks. SEM studies conducted at the Khabarovsk Analytical Innovation Center (Khabarovsk, Russia).

adakites and shoshonitic lamprophyres around $117 \mathrm{Ma}$ [11]. Aqueous fluids, also enriched in halogens (as evidenced from ubiquitous $\mathrm{Cl}-\mathrm{F}$ apatites and $\mathrm{K}-\mathrm{Cl}$ salt inclusions in biotite and pargasitic amphibole in ILC rocks) overprinted $\mathrm{Ni}-\mathrm{Co}-\mathrm{Cu}-\mathrm{PGE}$ mineralization with gold resulting in individual Au grades over $600 \mathrm{~g} / \mathrm{t}$ in some wehrlites and pyroxenites [11].

Electron Image 31

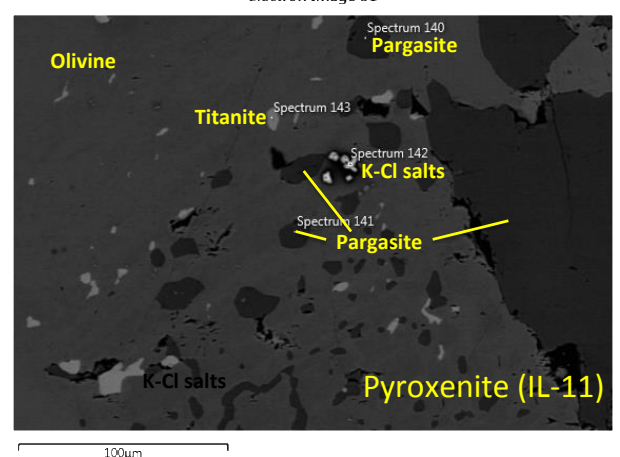

Electron Image 23

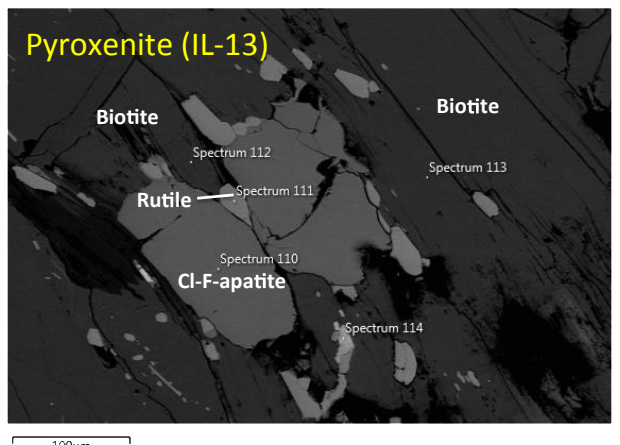

Fig. 4. Occurrence of $\mathrm{K}-\mathrm{Cl}$ salts in pargasitic amphibole (left image) and $\mathrm{Cl}-\mathrm{F}$-apatites in biotite (right image) from the ILC pyroxenites (Stanovoy super-terrane).

Bonanza-type gold grades (free native gold in ultramafic rocks; Figures 1 and 3) are frequently accompanied by elevated (up to $17.47 \mathrm{ppb}$ ) palladium concentrations in ILC ultramafic rocks. Eclogite-facies rocks in subduction zones are depleted in halogens suggesting release of halogen-rich fluids prior to eclogite-amphibolite transition in the subducting slab [16]. This, together with high gold solubility in slab-derived saline fluids [17], may account for well-documented gold enrichments in volcanic front magmas $[18,19]$. We propose that multi-stage metasomatism of depleted sub-arc mantle wedge in presence of metal-rich, saline slab-derived fluids coupled with further metal concentration in long-lived, arc-related plumbing systems may account for gold, platinum and palladium enrichments observed in modern arc environments and Phanerozoic accreted terranes [1$3,6,18,19]$. Most probably a combination of all these factors coupled with emplacement of metal-rich magmas along steep thermal gradients in arc crust in presence of saline aqueous fluids leads to the formation of giant metal deposits in modern and fossil subduction zones. 


\section{References}

1. J.J. Wilkinson, Nature Geosci., 6, 917-925 (2013)

2. P.K. Kepezhinskas, N.P. Kepezhinskas, Ext.Abstr. Conference on Strategic Metal Deposits, Miass, Russia (2017)

3. J.F. Mungall, Geology, 30, 915-918 (2002)

4. P.K. Kepezhinskas, M.J. Defant, Geology, 29, 851-854 (2001)

5. W. Sun, R.J. Arculus, V.S. Kamenetsky, R.A. Binns, Nature, 431, 975-978 (2004)

6. J.P. Richards, Ore Geol. Rev., 40, 1-26 (2011)

7. E. Widom, P. Kepezhinskas, M. Defant, Chem. Geol., 196, 283-306 (2003)

8. P.K. Kepezhinskas, M.J. Defant, E. Widom, Lithos, 60, 113-128 (2002)

9. E.V. Pushkarev, V. Kamenetsky, I. Gottman, G. Yaxley, In: E.V. Anikina et al. (Eds.), Proc. $12^{\text {th }}$ Int. Plat. Conf.,Yekaterinburg, Russia (2014)

10. J.-W. Park, I.H. Campbell, R.J. Arculus, Geochim. Cosmochim. Acta, 101, 76-95 (2013)

11. P.Kepezhinskas, N. Kepezhinskas, V. Kamenetsky, N. Berdnikov, GSA Abstracts with Programs, 50, doi : 10.1130/abs/2018AM-320293 (2018)

12. C.E. Manning, Earth Planet. Sci. Lett., 223, 1-16 (2004)

13. B. Debret, K.T. Koga, F. Cattani, C. Nicollet, Van den Bleeken, S. Schwartz, Lithos, 244, 165-181 (2016)

14. A.J.R. Kent, D.W. Peate, S. Newman, E.M. Stolper, J.A. Pearce, Earth Planet. Sci. Lett., 202, 361-377 (2002)

15. W.D. Sun, R.A. Binns, A.S. Fan, V.S. Kamenetsky, R. Wysoczanski, G.J. Wei, Y.H. Hu, R.J. Arculus, Geochim. Cosmochim. Acta, 71, 1542-1552 (2007)

16. L. Hughes, P. Burgess, D. Chavrit, A. Pawley, R. Tartese, G. Droop, C.J. Ballentine, I. Lyon, Geochim. Cosmochim. Acta, 243, 1-23 (2018)

17. S. Jego, M. Pichavant, Geochim. Cosmochim. Acta, 84, 560-592 (2012)

18. S.F. Simmons, V.L. Brown, Geology, 35, 1009-1102 (2007)

19. M. Zelenski, V. Kamenetsky, J. Hedenquist, Earth Planet. Sci. Lett., 437, 35-46 (2016) 